\title{
DETERMINATION OF PAH IN THE BLACK SEA WATER BY GC/MS FOLLOWING PRECONCENTRATION WITH SOLID-PHASE EXTRACTION
}

\author{
OZNACZANIE WWA W WODACH MORZA CZARNEGO \\ METODĄ GC/MS Z ZATĘŻANIEM \\ POPRZEZ EKSTRAKCJĘ DO FAZY STAŁEJ
}

\begin{abstract}
Determination of PAHs in marine coastal waters has to be carried out with great care to avoid serious losses occurring during the sampling and storage stage. This is due to the hydrophobic properties of PAHs, and their tendency to be adsorbed to surfaces they are in contact with, including suspended particulate matter. The best technique to separate PAHs is gas chromatography with mass spectrometer. Because of low concentration levels to be quantified in water samples, an enrichment step is needed before chromatographic analysis. For PAHs, several preconcentration techniques have been used, but the most concentration technique is solid-phase extraction (SPE). The main objective of this work is to adapt and implement a relatively simple and rapid method for gas chromatographic determination of individual PAHs in samples of coastal and running waters. The present work analyses the yield and precision of extraction of PAHs by solid phase extraction with using different sorbents for SPE (Bond Elut: C18 and Plexa SPE discs), the two most common methods used for aqueous samples.
\end{abstract}

Keywords: polycyclic aromatic hydrocarbons (PAHs), solid-phase extraction (SPE), different sorbents (Bond Elut: C18 and Plexa SPE discs), analysis of coastal waters

The monitoring of polycyclic aromatic hydrocarbons (PAHs) is an important problem due to their well-known mutagenic and carcinogenic effects [1, 2]. These substances can be found in various matrices, both biological and environmental. PAHs are typical non-polar compounds and have excellent retention on a reversed-phase adsorbent such as $\mathrm{C} 18$ bonded silica. Although their solubility in water is very low, concentrations in the $\mu \mathrm{g} \mathrm{dm}^{-3}$ level are commonly encountered in the environment. Since these compounds are considered toxic at this level, their presence needs to be monitored.

The Water Framework Directive [1] imposes on the EU Member States the obligation of monitoring natural water quality, including the marine coastal waters. Coastal seawater is a very specific matrix, quite different from inland waters, due to salinity and high particulate

\footnotetext{
${ }^{1}$ Institute of Biodiversity and Ecosystem Research - BAS, Y. Gagarin str. 2, Sofia 1113, Bulgaria, phone +35928717195 , fax +35928719138

*Corresponding author: ekraleva@gmail.com
} 
matter content. Shore waters are often under strong anthropogenic stress, which results amongst others in eutrophication, intensifying their turbidity in comparison with the open sea or ocean waters. Papers concerning PAHs in seawater are scarce, due to their very low concentrations in that matrix, in comparison with the concentrations in wastes, sewage, contaminated soils or marine sediments and even other aqueous matrices like rain water [3].

Determination of PAHs in marine coastal waters has to be carried out with great care to avoid serious losses occurring during the sampling and storage stage. This is due to the hydrophobicity of these compounds, and their tendency to be adsorbed to surfaces they are in contact with, including suspended particulate matter. The best technique to separate PAHs is gas chromatography with mass spectrometer. Because of low concentration levels to be quantified in water samples, an enrichment step is needed before chromatographic analysis.

In recent decades, the development of preconcentration steps in order to be implemented prior to analytical determinations of trace level compounds has been explored in considerable depth. With a view to eliminating or at least minimizing the use of organic solvents employed in conventional liquid-liquid extraction (LLE) [4-6], which has been used by the environmental protection agency (EPA), other methods have been developed. Among them, membrane extraction [7, 8], solid-phase extraction (SPE) [9, 10] or solid-phase microextraction (SPME) [11, 12] are the most common ones.

For PAHs, several preconcentration techniques have been used, but the most concentration technique is solid-phase extraction (SPE). SPE is a technique that is becoming increasingly popular, because unlike liquid-liquid extraction (LLE) it does not require large volumes of toxic organic solvents, analysis time can be decreased significantly and on-line and/or automated procedures are easily designed. Another advantage of SPE over LLE is the wide variety of extraction conditions which may be used to achieve the desired separation and concentration. The great variety of types of sorbents commerically available has increased the use of SPE.

The main objective of this work is to adapt and implement relatively simple and rapid method for gas chromatographic determination of individual PAHs in samples of coastal and transitional waters. The present work analyses the yield and precision of extraction of PAHs by solid phase extraction with using different sorbents for SPE (Bond Elut: C18 and Plexa SPE discs), the two most common used for aqueous samples.

\section{Experimental}

\section{Reagents and materials}

\section{Standards}

Standard 1: Standard mixtures of 16 PAHs $2000 \mu \mathrm{g} / \mathrm{cm}^{3}$ each in methylene chloride $\left(\mathrm{CH}_{2} \mathrm{Cl}_{2}\right)$ was used, SV Calibration Mix 16 RESTEK. For spiking, $1 \mathrm{~cm}^{3}$ from standard 1 was diluted with methylene chloride to $50 \mathrm{~cm}^{3}$. Additionally $0.02 \mathrm{~mm}^{3}(\mu \mathrm{L})$ of standard 1 was added to the seawater samples before SPE as an internal standard. 


\section{Sampling}

Samples were collected in June 2010 from the harbour of town of Sozopol, SW Black Sea coast, Bulgaria to assess the spatial PAHs distribution. Seawater was collected from the surface in $2.5 \mathrm{dm}^{3}$ bottles. After collection the samples were immediately transferred to the laboratory and stored under proper conditions. Seawater was kept at $2 \div 4^{\circ} \mathrm{C}$. We make analysis of 4 samples, all taking in area of town Sozopol.

\section{Analyses}

\section{Solid-phase extraction (SPE) procedure}

Pretreatment of seawater samples:

Pretreatment was performed at natural $\mathrm{pH} \sim 8.00$. Four subsamples of seawater, $500 \mathrm{~cm}^{3}$ each were filtered through glass-fibre filter Whatman GF/C (pore size $9.0 \mathrm{sm}$ ). In all $500 \mathrm{~cm}^{3}$ seawater samples $50 \mathrm{~cm}^{3}$ isopropyl alcohol was added and mixed thoroughly.

Steps of solid-phase extraction (SPE) procedure for determination PAHs in seawater

Conditioning: Add $5 \mathrm{~cm}^{3} \mathrm{CH}_{2} \mathrm{Cl}_{2}$ to the cartridge. Apply vacuum and discard the eluent. Repeat with $5 \mathrm{~cm}^{3}$ methanol $(\mathrm{MeOH})$ then $5 \mathrm{~cm}^{3}$ water. Do not allow the sorbent to dry at any point during this step.

Samples loading: Attach a $50 \mathrm{~cm}^{3}$ sample reservoir to the top of the cartridge. Add to the reservoir water sample in portions avoiding sorbent drying. Apply the vacuum and discard the eluent. The flow rate should be no greater than $10 \mathrm{~cm}^{3} / \mathrm{min}$. The literature listed different speeds to cause the sample to the solid-phase column. Most manufacturers recommend $5 \div 15 \mathrm{~cm}^{3} \cdot \mathrm{min}^{-1}$. We decided to work with speed of $10 \mathrm{~cm}^{3} \cdot \mathrm{min}^{-1}$ for two sorbents. Higher speeds lead to low retention volume. This can lead to losses in the extraction of these compounds that have retention volume close to the sample size.

Washing: Add $3 \mathrm{~cm}^{3}$ of acetonitrile/water (50/50) to the cartridge. Apply vacuum and discard the eluant. Leave the vacuum on for 30 seconds and after that repeat procedure for washed of samples.

Elution: Place a collection tube beneath the cartridge. Add $3 \mathrm{~cm}^{3}$ methylene chloride to the cartridge. Apply vacuum and collect the eluent. Concentrate to $50 \div 200 \mathrm{~mm}^{3}(\mu \mathrm{L})$ under a stream of dry nitrogen. Stop concentrating as close to $200 \mathrm{~mm}^{3}(\mu \mathrm{L})$ as possible. We not heat the samples during concentration - this will result in the substantial loss of many of the smaller ring size PAHs. Add methylene chloride to bring the final volume to $1000 \mathrm{~mm}^{3}(\mu \mathrm{L})$. Inject $1 \mathrm{~mm}^{3}(\mu \mathrm{L})$ into the GC/MS.

SPE cartridges: Agilent SampliQ C18 $6 \mathrm{~cm}^{3}, 50 \mathrm{~cm}^{3}$ sample reservoir (PN 5982-1365); Bond Elut Plexa VARIAN $6 \mathrm{~cm}^{3}, 50 \mathrm{~cm}^{3}$ sample reservoir (P/N 5982-9305); coupling fitting; vacuum manifold (12-port).

Reagents: water (deionization water); methanol; isopropyl alcohol; methylene chloride.

\section{Instrumentation}

Gas Chromatographic - Mass Spectrometric analyses (GC-MS) were carried out on a DSQ II MSD coupled to a Focous GC (Thermo Scientific). One $\mathrm{mm}^{3}$ ( $\mu \mathrm{L}$ ) samples were injected in splitless mode. The injector was heated at $290^{\circ} \mathrm{C}$. Separations were 
achieved using a capillary column coated with ZB-5MS (Zebron, $20 \mathrm{~m}, 0.18 \mathrm{~mm}$ i.d., $0.18 \mu \mathrm{m}$ film thickness) Phenomenex. The column temperature was programmed from 60 to $325^{\circ} \mathrm{C}$ at $8^{\circ} \mathrm{C} \mathrm{min}^{-1}$ and held at $300^{\circ} \mathrm{C}$ for $15 \mathrm{~min}$. Helium was used as carrier gas with constant velocity. Data acquisition was done at $\mathrm{EI}$ of $70 \mathrm{eV}$ and selected ion monitoring (SIM) mode was used. Two characteristic ions were selected for each compound to allow a better identification. The standard PAH mixture was also analyzed in SCAN mode in the mass range of $50 \div 400 \mathrm{Da}$. Before analysis, relevant standards (reference mixture of PAHs) were run to check column performance, peak heights and resolution. With each set of samples to be analyzed, a solvent blank and a standard mixture were run in sequence to check for contamination, peak identification and quantification.

\section{Results and discussion}

We present a validation method for the determination of 16 PAHs in which we use a semi-automated solid phase extraction (SPE) method, whit different sorbents in cartridges - Agilent SampliQ C18 and Bond Elut Plexa VARIAN, to concentrate the analyzed in a $500 \mathrm{~mL}$ water sample, with a further analysis by GC/MS technique.

The mass spectrometer is tuned daily meet the relative ion abundance requirements:

- A minimum of five concentration levels of each analyte are prepared to establish calibration factors with $<20 \%$ variance over the linear working range of the calibration curve. The linear calibration curves were obtained by plotting the peak area of each compound versus its concentration. The limits of detection and quantification were evaluated from the concentration of sulphonamides required to give a signal-to-noise ratio of 3 to 10 - respectively. Table 1 show the correlation coefficient and retention time for all PAHs.

Table 1

Calibration table for PAHs

\begin{tabular}{|c|c|c|c|}
\hline PAHs & $\begin{array}{c}\text { Molecular Ion } \\
\text { (from experiment) }\end{array}$ & $\begin{array}{c}\text { Retention time } \\
\text { (from experiment) }\end{array}$ & $\begin{array}{c}\text { Linearity } \\
\mathbf{R}^{\mathbf{2}}\end{array}$ \\
\hline 1. Naphthalene & 128.10 & 6.06 & 0.9991 \\
\hline 2. Acenaphthylene & 152.13 & 9.55 & 0.9988 \\
\hline 3. Acenaphthene & $152.16 ; 154$ & 9.97 & 0.9991 \\
\hline 4. Fluorene & $166 ; 165$ & 11.18 & 0.9990 \\
\hline 5. Phenanthrene & $178 ; 176$ & 13.38 & 0.9991 \\
\hline 6. Anthracene & $178 ; 176$ & 13.50 & 0.9991 \\
\hline 7. Fluoranthene & $202.11 ; 200$ & 16.28 & 0.9996 \\
\hline 8. Pyrene & $202 ; 200$ & 16.68 & 0.9998 \\
\hline 9. Benz[a]anthracene & $228 ; 226$ & 19.73 & 0.9988 \\
\hline 10. Chrysene & 228 & 19.82 & 0.9975 \\
\hline 11. Benzo[b]fluoranthene & $252 ; 250$ & 22.16 & 0.9972 \\
\hline 12. Benzo[k]fluoranthene & 252 & 22.21 & 0.9988 \\
\hline 13. Benzo[a]fluoranthene & 252.06 & 22.84 & 0.9990 \\
\hline 14. Dibenzo[a,h]anthracene & $276.12 ; 274$ & 26.03 & 0.9984 \\
\hline 15. Indeno[1,2,3-cd]pyrene & 278 & 26.20 & 0.9996 \\
\hline 16. Benzo[ghi]perylene & 276 & 26.95 & 0.9991 \\
\hline
\end{tabular}

- The initial calibration curve is verified each working day by the measurement of a mid-scale standard. The predicted response must not vary by more than $\pm 20 \%$. 
- Additional validation of the GC/MS performance is determined by surrogate standard recovery. The recovery of the surrogate standard should deviate from $100 \%$ (C18) by less than $20 \%$ (Plexa).

- The abundance ratio of qualifying to quantitation ions was within $\pm 20 \%$ of target levels. (Example: for an ion with abundance relative to the quantization ion of $50 \%$ in the standard spectrum, the corresponding sample ion abundance must be between 30 and $70 \%$ of the quantization ion abundance).

The first step was to optimize a chromatographic separation for PAHs, using a capillary column coated with ZB-5MS (Zebron, $20 \mathrm{~m}, 0.18 \mathrm{~mm}$ i.d., $0.18 \mu \mathrm{m}$ film thickness) working in isothermal program. This type column give as better separation and identification of PAHs in seawater samples (Figure 1 and Table 1). The results are obtained operating in SIM mode for the standard solution.

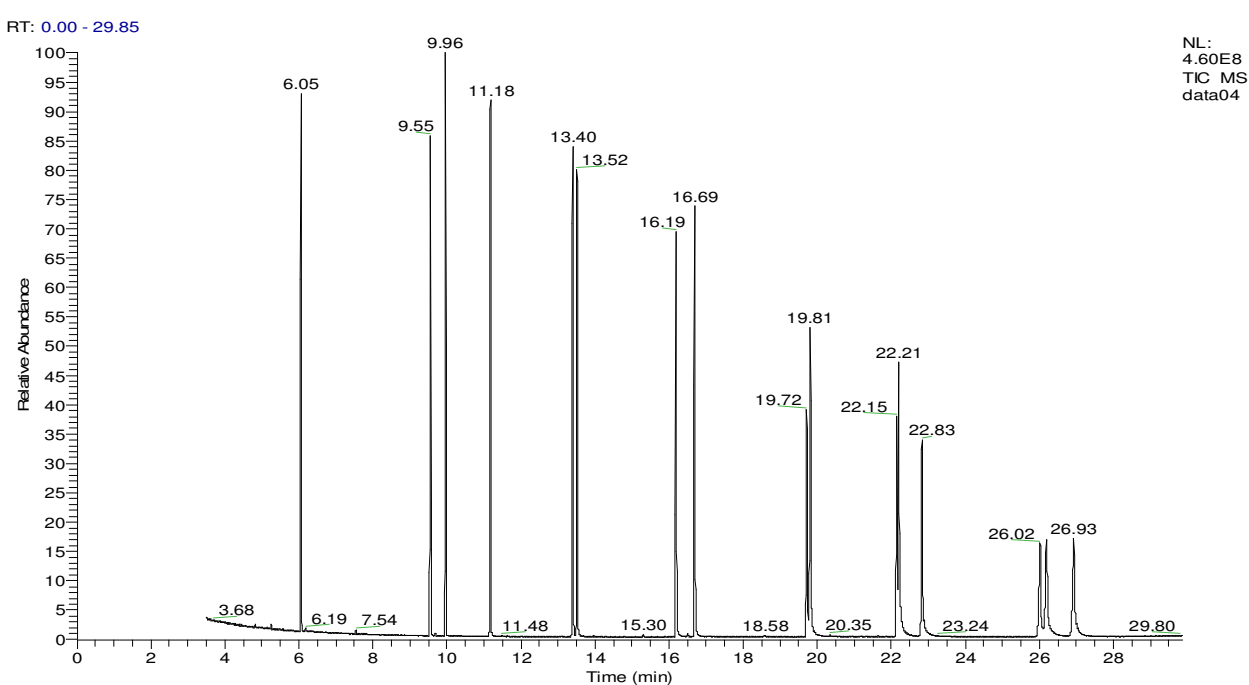

Fig. 1. GC analysis of Standard PAH Mix 16 (Agilent). Identification of compounds with retention times are presented in Table 1

The second step in our work was the optimization of the SPE method. We tested polymer- and silica-based sorbents, drying time and optimized the recoveries by adding iso-propanol to provide a final concentration of $5 \%$ in the water sample.

Pretreatment of samples make in identifiable conditions with using of different sorbents. Specific characteristic of two types of cartridge sorbents are presented in Table 2.

The Agilent SampliQ C18 sorbent is based on octadecylsilane-bonded, irregular silica gel (silica) particles. This non-polar, non-end capped sorbent provides reversed-phase binding of hydrophobic compounds. In addition, polar interactions are associated with the surface silanol groups.

Agilent SampliQ C18 is recommended as a general purpose SPE phase for both polar and non-polar analyses. The SampliQ C18 sorbent provides highly reproducible recoveries for a wide range of compounds following a simple protocol. C18 is generally regarded as the least selective silica-based sorbent, since it retains most organic analytes from aqueous 
matrices. When analyzing small to intermediate molecules, C18 can be used for desalting aqueous matrices prior to ion exchange, as salts pass through the sorbent unretained.

Table 2

Sorbent specifications

\begin{tabular}{|c|c|c|c|c|c|c|c|}
\hline Sorbent phase & Category & $\begin{array}{c}\text { Bonded } \\
\mathbf{f u n c t i o n a l} \\
\text { group/ Base } \\
\text { material }\end{array}$ & Format & $\begin{array}{c}\text { Typical } \\
\text { carbon } \\
\text { loading } \\
{[\%]}\end{array}$ & $\begin{array}{c}\text { Surface } \\
\text { area } \\
{\left[\mathbf{m}^{\mathbf{2}} / \mathbf{g}\right]}\end{array}$ & $\begin{array}{c}\text { Particle size } \\
{[\boldsymbol{\mu M}] \text { and }} \\
\text { shape }\end{array}$ & $\begin{array}{c}\text { Mean pore } \\
\text { size }[\AA]\end{array}$ \\
\hline $\begin{array}{c}\text { Agilent SampliQ } \\
\text { C18 }\end{array}$ & Non-polar & $\begin{array}{c}\text { Trifunctional } \\
\text { octadecyl/ } \\
\text { silica based }\end{array}$ & $\begin{array}{c}\text { Packed } \\
\text { bed }\end{array}$ & 17.4 & 500 & $\begin{array}{c}40 \text { and } 120, \\
\text { irregular }\end{array}$ & 60 \\
\hline $\begin{array}{c}\text { Bond Elut Plexa } \\
\text { VARIAN }\end{array}$ & $\begin{array}{c}\text { Polar } \\
\text { enhanced }\end{array}$ & $\begin{array}{c}\text { Hydrophilic } \\
\text { styrene } \\
\text { divinylbenzene }\end{array}$ & $\begin{array}{c}\text { Packed } \\
\text { bed }\end{array}$ & - & 550 & $\begin{array}{c}45 \text {, spherical } \\
\text { monodisperse }\end{array}$ & 100 \\
\hline
\end{tabular}

Bond Elut Plexa is a new generation of polymeric SPE products, designed for simplicity, improved analytical performance and ease-of-use. Its uniqueness lies in the novel hydroxylated exterior, hydrophobic interior and advanced polymeric architecture. Bond Elut Plexa, with an internal polar surface, is universally applicable and the best choices for the extraction of a wide range of acidic, neutral and basic analyses from different matrices. Bond Elut Plexa PCX is a cation exchanger with mixed mode sorbent characteristics and therefore suitable for the extraction and clean up of bio-matrix. Bond Elut Plexa PCX demonstrates the same excellent particle size distribution and integrity as Bond Elut Plexa.

M.C. Díaz Ramos and al [13] showed that the combination of the Agilent Pursuit PAH $3 \mu \mathrm{m}$ HPLC column and automated SPE on Bond Elut Plexa provide a perfect and fast solution for the analysis of 24 PAHs from a large volume of water. The results of explained measurements [13] determine our decision to tested Bond Elut Plexa in process of SPE of coastal and running sea-water.

We make analysis of 4 samples, all taking in area of town Sozopol. Samples were collected in June 2010 from the harbour of town, SW Black Sea coast, Bulgaria to assess the spatial PAHs distribution. Pretreatment was performed at natural $\mathrm{pH} \sim 8.00$. Four subsamples of seawater, $500 \mathrm{~cm}^{3}$ each were filtered and in all samples $50 \mathrm{~cm}^{3}$ isopropyl alcohol was added and mixed thoroughly. Procedure of solid-phase extraction (SPE) for determination PAHs for all samples is identical. The literature listed at different speeds to move the sample to the solid-phase column. Cited rates vary quite a wide range: from $2 \div 5 \mathrm{~cm}^{3} \cdot \mathrm{min}^{-1}, 10 \div 30 \mathrm{~cm}^{3} \cdot \mathrm{min}^{-1}$ or even up to $100 \mathrm{~cm} \cdot \mathrm{min}^{-1}$. Most manufacturers recommend $5 \div 15 \mathrm{~cm}^{3} \cdot \mathrm{min}^{-1}$. You decided to work with specimen is $10 \mathrm{~cm}^{3} \cdot \mathrm{min}^{-1}$. Higher speeds lead to low retention volume. After elution of samples from different sorbents cartridges injected $1 \mathrm{~mm}^{3}$ ( $\mu \mathrm{L}$ ) into the GC/MS for analysis.

When comparing results after GC/MS analysis of samples, concentrated by two different sorbents, results are very different. The results show that the effect of sorbents type for extraction efficiency varies greatly among different PAH species. Compared with C18 and Plex extracted water samples, the efficiencies for all 15 PAHs without of naphthalene are higher for C18. Parameters that affect the efficiency of SPE with C18 columns are: the salt, organic content, flow rate through the sample columns for SPE, the method of drying the column after loading the sample, elution of PAHs and $\mathrm{pH}$ of samples. In principal the 
salt content reduces the extraction efficiency for all the PAHs except naphathene [14]. On the other hand, the presence of excessive salt in water could lead to a change of the physical configuration of the chemical functionalities on the surface coating, which would then depresses the extraction efficiency.

Table 3

Real concentrations of PAHs in seawater samples from Sozopol, pretreated by different SPE Sorbent: Bond Elut Plexa VARIAN and $* \mathrm{C} 18$ Agilent in identical condition of area $-\mathrm{pH}=8$ and $\mathrm{S}=16.4$

\begin{tabular}{|c|c|c|c|c|c|c|c|c|}
\hline PAHs & \multicolumn{2}{|c|}{$\begin{array}{c}\text { Concentration } \\
{\left[\boldsymbol{\mu g} / \mathbf{c m}^{\mathbf{3}}\right]}\end{array}$} & \multicolumn{2}{c|}{$\begin{array}{c}\text { Concentration } \\
{\left[\boldsymbol{\mu g} / \mathbf{c m}^{\mathbf{3}}\right]}\end{array}$} & \multicolumn{2}{c|}{$\begin{array}{c}\text { Concentration } \\
{\left[\boldsymbol{\mu g} / \mathbf{c m}^{\mathbf{3}}\right]}\end{array}$} & \multicolumn{2}{c|}{$\begin{array}{c}\text { Concentration } \\
{\left[\boldsymbol{\mu g} / \mathbf{c m}^{\mathbf{3}}\right]}\end{array}$} \\
\hline & $\mathbf{1}$ & $\mathbf{1 . 1}$ & $\mathbf{2}$ & $\mathbf{2 . 2}$ & $\mathbf{3}$ & $\mathbf{3 . 3}$ & $\mathbf{4}$ & $\mathbf{4}^{*}$ \\
\hline Naphthalene & 10.62 & 10.07 & 5.8 & 8.73 & 12.37 & 7.25 & 7.78 & 4.87 \\
\hline Acenaphthylene & 0.181 & 21.84 & 0.24 & 19.4 & 0.22 & 16.9 & 0.164 & 10.19 \\
\hline Acenaphthene & 0.216 & 23.92 & 0.21 & 18.882 & 0.22 & 16.6 & 0.144 & 10.3 \\
\hline Fluorene & 0.186 & 24.9 & 0.29 & 20.89 & 0.161 & 17.69 & 0.158 & 10.556 \\
\hline Phenanthrene & 0.230 & 25.0 & 0.71 & 21.156 & 0.276 & 17.5 & 0.177 & 9.1 \\
\hline Anthracene & 0.310 & 25.12 & 0.70 & 20.993 & 0.235 & 17.86 & 0.043 & 9.09 \\
\hline Fluoranthene & 0.369 & 25.01 & 0.55 & 19.3 & 0.256 & 16.127 & 0.230 & 7.6 \\
\hline Pyrene & 0.210 & 24.5 & 0.63 & 18.68 & 0.295 & 15.6 & 0.162 & 7.5 \\
\hline Benzo[a]anthracene & $\mathrm{nf}$ & 17.7 & 0.22 & 15.3 & $\mathrm{nf}$ & 12.25 & $\mathrm{nf}$ & 5.1 \\
\hline Chrysene & 0.3 & 19.1 & 1.44 & 17.4 & 0.010 & 13.29 & $\mathrm{nf}$ & 5.76 \\
\hline Benzo[b]fluoranthene & 0.331 & 17.24 & 0.05 & 17.77 & $\mathrm{nf}$ & 12.7 & $\mathrm{nf}$ & 5.22 \\
\hline Benzo[k]fluoranthene & 1.486 & 16.88 & 1.90 & 16.0 & 0.944 & 11.58 & 0.089 & 4.65 \\
\hline Benzo[a]fluoranthene & 0.36 & 16.36 & 0.16 & 15.65 & $\mathrm{nf}$ & 11.45 & $\mathrm{nf}$ & 4.7 \\
\hline Dibenzo[a,h]anthracene & $\mathrm{nf}$ & 17.18 & 0.68 & 16.94 & $\mathrm{nf}$ & 12.26 & $\mathrm{nf}$ & 5.25 \\
\hline Indeno[1,2,3-cd]pyrene & $\mathrm{nf}$ & 15.07 & 0.55 & 14.56 & $\mathrm{nf}$ & 10.15 & $\mathrm{nf}$ & 4.7 \\
\hline Benzo[ghi]perylene & 0.579 & 15.9 & 0.65 & 15.18 & $\mathrm{nf}$ & 9.28 & $\mathrm{nf}$ & 4.54 \\
\hline
\end{tabular}

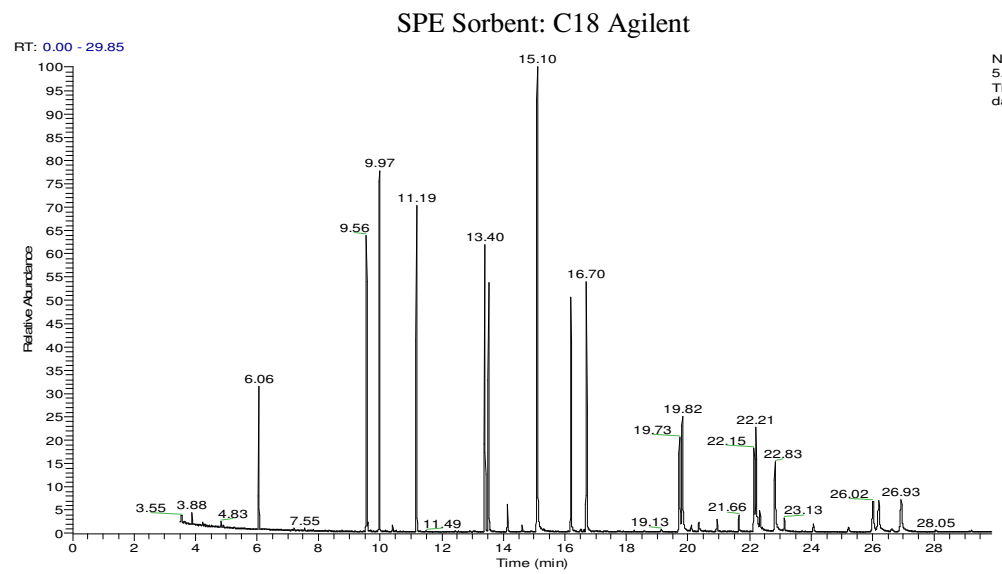




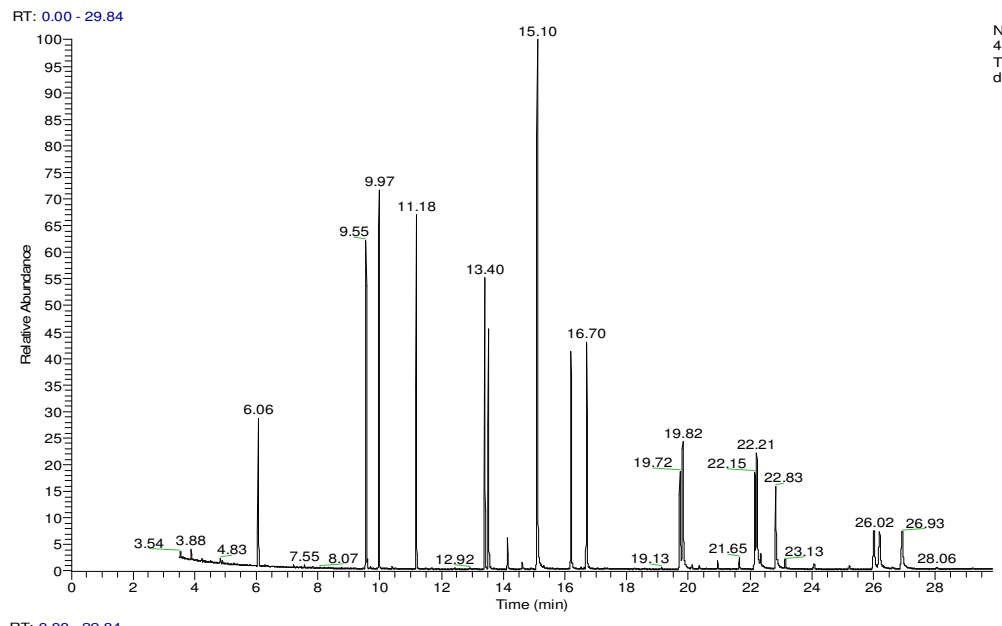

NL:
$4.97 \mathrm{E} 8$

TIC MS
data08

RT: $0.00-29.84$

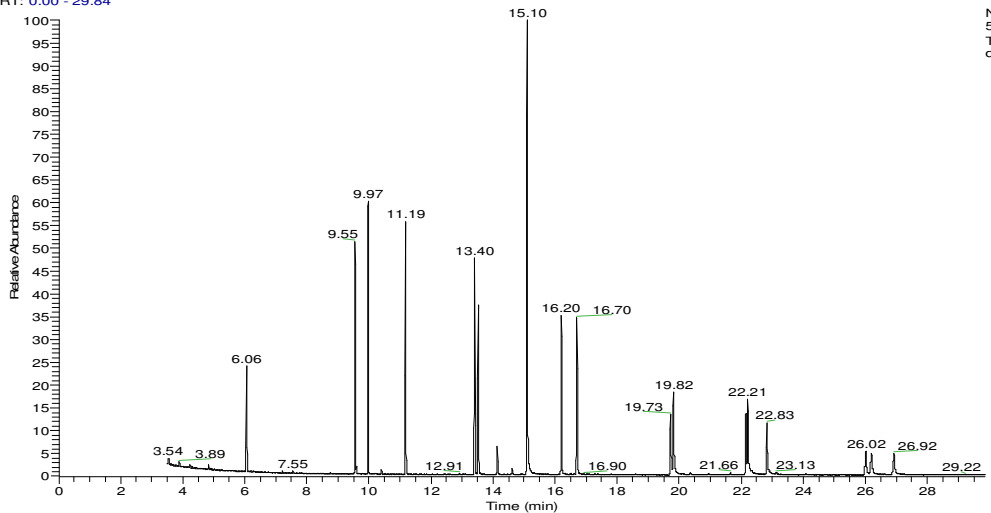

NL:
5.01E8
TIC MS
Th

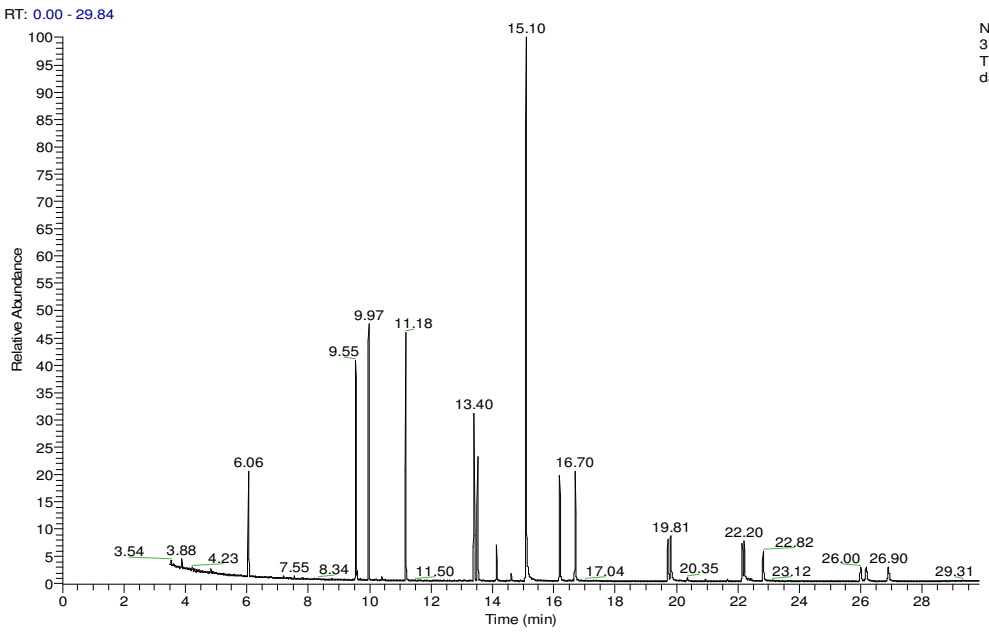



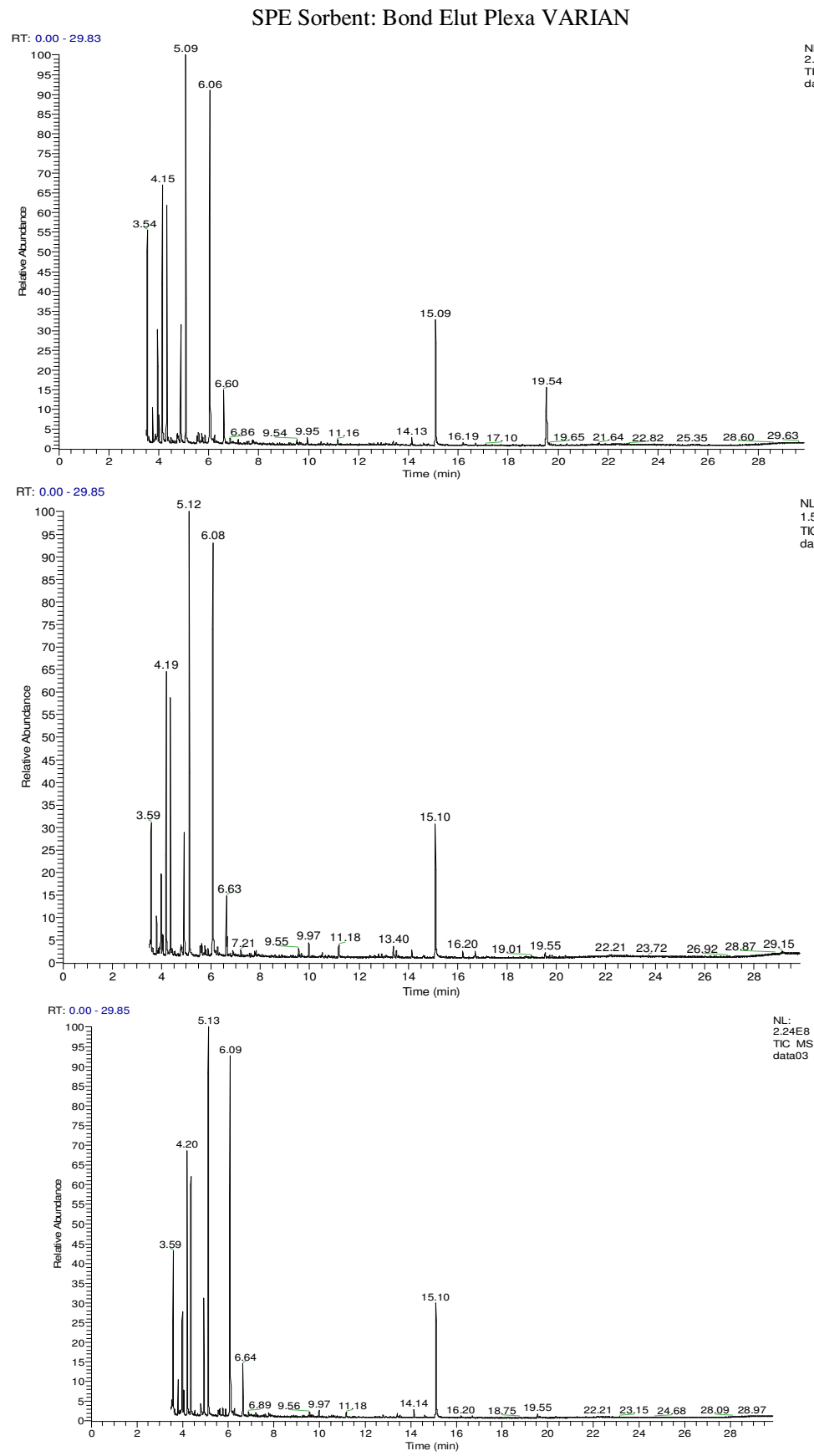

NL:

TIC MS
data02

NL:
$2.24 E 8$
TIC MS

Tata01

data03 


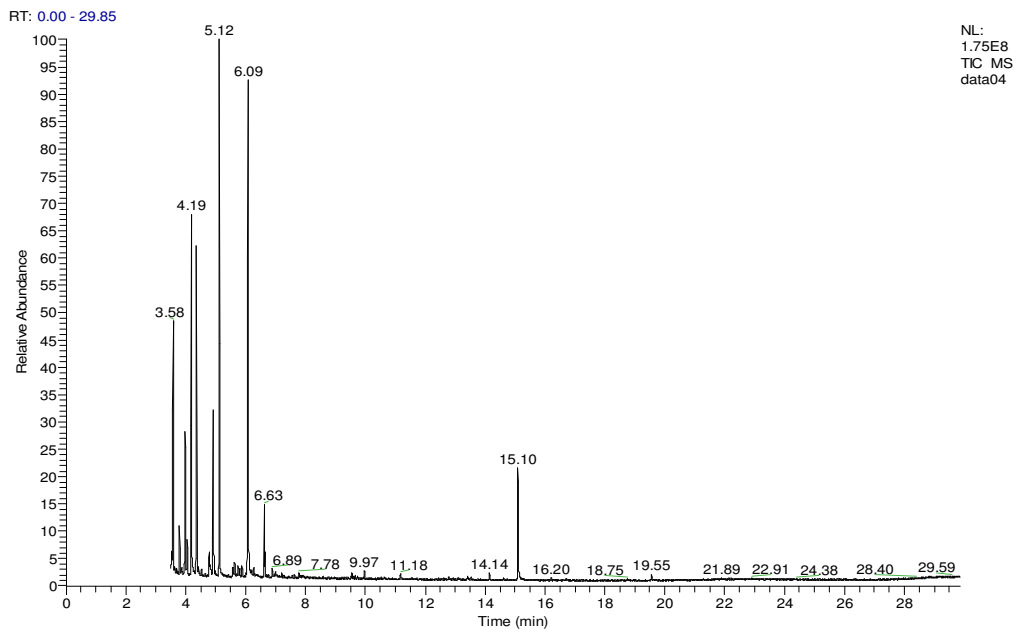

Fig. 2. Chromatogram of seawater samples analysis from Sozopol $(\mathrm{pH}=8$ and $\mathrm{S}=16.4)$

\section{Conclusions}

Depending of our application or sample type (seawater), we will appreciate the difference the Plexa and C18 range of products makes. Matrix interferences can result in significantly decreased analytical sensitivity due to ion suppression. C18 sorbents gives you higher recoveries in cleaner extracts, which translates into better sensitivity. C18 delivers high recoveries regardless of whether absolute or relative calculations are used. This indicates that ion suppression is minimized and maximum sensitivity is achieved. Relative recovery calculations are routinely used, but mask the effects of ion suppression, which are normalized.

For analysis of seawater samples, $\mathrm{C} 18$ is better sorbents because:

- Extremely retentive for non-polar compounds,

- Effective for desalting aqueous mixtures,

- The most hydrophobic, bonded silica sorbent.

\section{References}

[1] Dabestani R, Ivanov IN. Photochem Photobiol. 1999;70:10-34. DOI: 10.1111/j.1751-1097.1999.tb01945.x.

[2] Braga RS, Barone PMVB, Galvao DS. J Mol Struct. 1999;464:257-266. DOI: 10.1016/S01661280(98)00557-0.

[3] Jones KC, Stratford JA, Waterhouse KS, Vogt NB. Environ Sci Technol. 1989;23:540-550. DOI: 10.1021/es00063a005.

[4] Futoma DJ, Smith S, Smith TE, Tanaka J. Polycyclic Aromatic Hydrocarbons in Water Systems. Boca Raton: CRC Press; 1983. P. 25.

[5] Pensado L, Blanco E, Casais MC, Mejuto MC, Martinez E, Carro AM, Cela R. J Chromatogr A. 2004;1056:121-30. DOI: 10.1016/j.chroma.2004.04.066.

[6] Method 550.0, Washington: US Environmental Protection Agency; 1990.

[7] Van de Merbel NC, Hageman JJ, Brinkman UATh. J Chromatogr. 1993;634:1-29. DOI: 10.1016/0021-9673(93)80308-U. 
[8] Carabias-Martınez R, Rodrıguez-Gonzalo E, Paniagua-Marcos PH, Hernández-Méndez J. J Chromatogr A. 2000;869:427-439. DOI: 10.1016/S0021-9673(99)01218-2.

[9] Hennion MC. J Chromatogr A. 1999; 856: 3-54. DOI: 10.1016/j.bbr.2011.03.031.

[10] Carabias-Martınez R, Rodrıguez-Gonzalo E, Domınguez-Álvarez J, Hernández-Méndez J. J Chromatogr A. 2000;869:451-461. DOI: 10.1016/S0021-9673(99)01273-X.

[11] Buchholtz KD, Pawliszyn J. Anal Chem. 1994;66:160-167. DOI: 10.1021/ac00073a027.

[12] Boyd-Boland AA, Magdic S, Pawliszyn J. Analyst. 1996;121:929-937. DOI: 10.1039/AN9962100929.

[13] Díaz Ramos MC, Suárez A, Rúbies A, Companyó R. Laboratori de l'Agencia de Salut, Publica de Barcelona, Spain; Determination of 24 PAHs in Drinking Water; Application Note. 2011.

[14] Qingling L, Xiaoqin X, Lee Chun-Sen Fr, Xiaoru W. Science in China Series B: Chem. 2006;49:481-491. DOI: $10.1007 / \mathrm{s} 11426-006-2026-5$.

\title{
OZNACZANIE WWA W WODACH MORZA CZARNEGO METODĄ GC/MS Z ZATĘŻANIEM POPRZEZ EKSTRAKCJĘ DO FAZY STALEJ
}

\begin{abstract}
Abstrakt: Oznaczanie WWA w przybrzeżnych wodach morskich należy przeprowadzać z wielką starannością, aby uniknąć dużych strat $\mathrm{w}$ trakcie pobierania próbek i ich przechowywania. Wynika to $\mathrm{z}$ właściwości hydrofobowych WWA i ich skłonności do adsorpcji na powierzchniach, z którymi mają kontakt. Najlepszą techniką rozdziału WWA jest chromatografia gazowa sprzężona ze spektrometrią masową. Z powodu małych stężeń WWA w próbkach wody konieczne jest ich zatężenie przed analizą chromatograficzną. Stosuje się kilka technik zatężania WWA, jednak najlepsze wyniki daje ekstrakcja do fazy stałej (SPE). Głównym celem pracy było dostosowanie i wdrożenie stosunkowo prostej i szybkiej metody chromatografii gazowej do oznaczania poszczególnych WWA w próbkach wód przybrzeżnych i wód płynących. W pracy przeanalizowano wydajność i precyzję ekstrakcji WWA przez zatężanie w fazie stałej z wykorzystaniem dwóch różnych sorbentów (Bond Elut: C18 i dysków Plexa SPE), najczęściej stosowanych w analizie próbek wodnych.
\end{abstract}

Słowa kluczowe: wielopierścieniowe węglowodory aromatyczne (WWA), ekstrakcja do fazy stałej (SPE), różne sorbenty (Bond Elut: C18 i dyski Plexa SPE), analiza wód przybrzeżnych 